\title{
QUEEN'S
UNIVERSITY
BELFAST
}

\section{Water-in-CO2 microemulsions stabilized by an efficient catanionic surfactant}

Sagisaka, M., Saito, Tatsuya, T., Masashi, A., Yoshizawa, A., Blesic, M., Rogers, S., Shirin, A., Guittard, F., Hill, C., \& Eastoe, J. (2020). Water-in-CO2 microemulsions stabilized by an efficient catanionic surfactant. Langmuir. https://doi.org/10.1021/acs.langmuir.0c00970

\section{Published in:}

Langmuir

\section{Document Version:}

Peer reviewed version

Queen's University Belfast - Research Portal:

Link to publication record in Queen's University Belfast Research Portal

\section{Publisher rights}

Copyright 2020 American Chemical Society. This work is made available online in accordance with the publisher's policies. Please refer to any applicable terms of use of the publisher.

\section{General rights}

Copyright for the publications made accessible via the Queen's University Belfast Research Portal is retained by the author(s) and / or other copyright owners and it is a condition of accessing these publications that users recognise and abide by the legal requirements associated with these rights.

Take down policy

The Research Portal is Queen's institutional repository that provides access to Queen's research output. Every effort has been made to ensure that content in the Research Portal does not infringe any person's rights, or applicable UK laws. If you discover content in the Research Portal that you believe breaches copyright or violates any law, please contact openaccess@qub.ac.uk. 
This document is confidential and is proprietary to the American Chemical Society and its authors. Do not copy or disclose without written permission. If you have received this item in error, notify the sender and delete all copies.

\section{Water-in- $\mathrm{CO}_{2}$ microemulsions stabilized by an efficient catanionic surfactant}

\begin{tabular}{|r|l|}
\hline Journal: & Langmuir \\
\hline Manuscript ID & la-2020-00970b.R3 \\
\hline Manuscript Type: & Article \\
\hline Author: & 12-Jun-2020 \\
\hline Complete List of Authors: & $\begin{array}{l}\text { Sagisaka, Masanobu; Hirosaki University, Graduate School of Science } \\
\text { and Technology } \\
\text { Saito, Tatsuya; Hirosaki University, Graduate School of Science and } \\
\text { Technology } \\
\text { Abe, Masashi; Hirosaki University, Graduate School of Science and } \\
\text { Technology } \\
\text { Yoshizawa, Atsushi; Hirosaki University, Department of Frontier } \\
\text { Materials Chemistry } \\
\text { Blesic, Marijana; Queen's University Belfast, School of Chemistry and } \\
\text { Chemical Engineering } \\
\text { Rogers, Sarah; ISIS-STFC Neutron Scattering Facility, Harwell Science } \\
\text { and Innovation Campus } \\
\text { Alexander, Shirin; Swansea University, College of Engineering } \\
\text { Guittard, Frédéric; Universite Cote d'Azur } \\
\text { Hill, Christopher; University of Bristol, School of Chemistry } \\
\text { Eastoe, Julian; University of Bristol, School of Chemistry }\end{array}$ \\
\hline
\end{tabular}

\section{SCHOLARONE Manuscripts}




\title{
Water-in- $\mathrm{CO}_{2}$ microemulsions stabilized by an efficient
}

\section{catanionic surfactant}

\author{
Masanobu Sagisakal*, Tatsuya Saito ${ }^{1}$, Masashi Abe ${ }^{1}$, Atsushi Yoshizawal, Marijana Blesic ${ }^{2}$, \\ Sarah E. Rogers ${ }^{3}$, Shirin Alexander ${ }^{4}$, Frédéric Guittard $^{5}$, Christopher Hill $^{6}$, Julian Eastoe $^{6}$ \\ ${ }^{1}$ Department of Frontier Materials Chemistry, Graduate School of Science and Technology, Hirosaki \\ University, 3 Bunkyo-cho, Hirosaki, Aomori 036-8561, JAPAN \\ ${ }^{2}$ School of Chemistry and Chemical Engineering, Queen's University Belfast, University Road, Belfast, \\ BT7 1NN, U.K. \\ ${ }^{3}$ ISIS-CCLRC, Rutherford Appleton Laboratory, Chilton, Oxon OX11 0QX, U.K. \\ ${ }^{4}$ Energy Safety Research Institute (ESRI), Swansea University, Bay Campus, Swansea SA1 8EN, UK. \\ ${ }^{5}$ Univ. Cote d'Azur, NICE-Lab, 61-63 av. S. Viel, 06200 Nice, France \\ ${ }^{6}$ School of Chemistry, University of Bristol, Cantock’s Close, Bristol BS8 1TS, U.K. \\ *To whom all correspondence should be addressed
}

Masanobu SAGISAKA E-mail: sagisaka@hirosaki-u.ac.jp Phone and Fax: +81-172-39-3579 


\begin{abstract}
To facilitate potential applications of water-in-supercritical $\mathrm{CO}_{2}$ microemulsions $\left(\mathrm{W} / \mathrm{CO}_{2} \mu \mathrm{Es}\right)$ efficient and environmentally responsible surfactants are required with low levels fluorination. As well as being able to stabilize water- $\mathrm{CO}_{2}$ interfaces, these surfactants must also be economical, prevent bioaccumulation and strong adhesion, deactivation of enzymes, and also be tolerant to high salt environments. Recently, an ion paired catanionic surfactant with environmentally-acceptable fluorinated $\mathrm{C}_{6}$-tails was found to be very effective at stabilizing $\mathrm{W} / \mathrm{CO}_{2} \mu$ Es with high water-to-surfactant molar ratios $\left(W_{0}\right)$ up to $\sim 50$ (Sagisaka, M. et al. Langmuir, 2019, 35, 3445-3454). As the cationic and anionic constituent surfactants alone did not stabilize $\mathrm{W} / \mathrm{CO}_{2} \mu \mathrm{Es}$, this was the first demonstration of surfactant synergistic effects in $\mathrm{W} / \mathrm{CO}_{2}$ microemulsions. The aim of this new study is to understand the origin of these intriguing effects by detailed investigations of nanostructure in $\mathrm{W} / \mathrm{CO}_{2}$ microemulsions using high pressure smallangle neutron scattering (HP-SANS). These HP-SANS experiments have been used to determine the headgroup interfacial area and volume, aggregation number and effective packing parameter (EPP). These SANS data suggest the effectiveness of this surfactant originates from increased EPP and decreased hydrophilic/ $\mathrm{CO}_{2}$-philic balance, related to a reduced effective headgroup ionicity. This surfactant bears separate $\mathrm{C}_{6} \mathrm{~F}_{13}$-tails and oppositely-charged headgroups, and was found to have a EPP value similar to that of a double $\mathrm{C}_{4} \mathrm{~F}_{9}$-tail anionic surfactant $\left(4 \mathrm{FG}(\mathrm{EO})_{2}\right)$, which was previously reported to be one of most efficient stabilizers for $\mathrm{W} / \mathrm{CO}_{2} \mu \mathrm{Es}$ (maximum $W_{0}=60-80$ ). Catanionic surfactants based on this new design will be key for generating super-efficient $\mathrm{W} / \mathrm{CO}_{2} \mu \mathrm{Es}$ with high stability and water solubilization.
\end{abstract}

Keywords: Supercritical $\mathrm{CO}_{2}$, Microemulsion, Catanionic Surfactant, Solubilizing Power, Small-Angle Neutron Scattering 


\section{Introduction}

Supercritical $\mathrm{CO}_{2}\left(\mathrm{scCO}_{2}\right)$ is now widely used industrially as an alternative solvent to replace volatile organic compounds (VOCs) for organic synthesis, dry cleaning, polymerization, extraction, and nanomaterial processing amongst others ${ }^{1}$. For these applications there are numerous advantages of $\mathrm{scCO}_{2}$ such as low cost, non-toxicity, non-flammability, natural abundance, a solvent quality tunable by control over pressure and temperature, and elimination of energy-consuming solvent evaporation steps in separation processes ${ }^{1}$. One of the drawbacks of pure $\mathrm{scCO}_{2}$ for applications is the inherent low solubility of polar solutes: approaches to overcome this are required to help develop further industrial applications of $\mathrm{scCO}_{2}$. An obvious way to enhance low solubility is though formation of water-in-scCO$\left(\mathrm{W} / \mathrm{CO}_{2}\right)$ dispersions, including microemulsions ( $\mu \mathrm{Es}$ ) and macroemulsions (emulsions): numerous surfactants have been tested to accomplish this task ${ }^{2-13}$. However, conventional hydrocarbon (HC) surfactants typically used for analogous water-oil $\mu$ Es, including Aerosol-OT (sodium bis-(2-ethyl-1-hexyl) sulfosuccinate, $\mathrm{AOT})^{14}$, are essentially incompatible with pure $\mathrm{scCO}_{2}{ }^{3-7}$. On the other hand, some specialized tailor-made fluorocarbon (FC) surfactants have been found to display high affinity for $\mathrm{scCO}_{2}$, and are able to stabilize $\mathrm{W} / \mathrm{CO}_{2} \mu \mathrm{Es}$ with modest water-to-surfactant molar ratios $>10\left(W_{0}=\right.$ [water]/[surf]). ${ }^{7-13}$ These $\mathrm{CO}_{2}$-philic FC surfactants may consist of either perfluoropolyether (PFPE)-tails, double FC-tail and FC-HC hybrid-tail structures. ${ }^{7-13}$ For example, a single PFPE-tail surfactant $\left(\mathrm{PFPECOONH}_{4}\right)$, a hybrid surfactant having perfluorohexyl and $n$-butyl tails (FC6-HC4), and double perfluorocarbon-tail surfactants $\left(8 \mathrm{FS}(\mathrm{EO})_{2}, 8 \mathrm{FG}(\mathrm{EO})_{2}\right.$ and $\left.4 \mathrm{FG}(\mathrm{EO})_{2}\right)$ (Figure S1 for chemical structures) have been shown to stabilize $\mathrm{W} / \mathrm{CO}_{2} \mu$ Es with maximum $W_{0}\left(W_{0}{ }^{\text {max }}\right)$ values up to 20,80 and 45-80, respectively. ${ }^{7-13}$ These surfactants mentioned are mainly anionic which presents problems for applications, including, difficulties of removing ionic surfactants from processes producing nanoparticles, deactivation with enzymatic reactions, surfactant-dye complexation in dyeing, and salting-out at high salinities typical in enhanced oil recovery $(\mathrm{EOR})^{15-19}$. For industrial applications $\mathrm{CO}_{2}$-philic surfactants should ideally be composed of (1) $\mathrm{CO}_{2}$-philic tails with low fluorination for reducing cost and environmental impact, and (2) possess nonionic or weakly ionic headgroups to minimize salting out. 
Earlier studies 20,21 investigated synergistic effects on interfacial properties of $\mathrm{scCO}_{2}$-philic surfactants by mixing HC, FC and FC-HC surfactants (Figure S1). Mixing commercial nonionic HC surfactants (TMN-6 and L31, Figure S1) with fluorinated surfactants reduced the critical microemulsion concentration $(c \mu c)$, which is defined as the lowest surfactant concentration to yield a microemulsion, compared to the individual surfactants, however, synergistic effects were not observed in terms of the water-solubilization $W_{0}{ }^{20}$. On the other hand, mixing 8FS(EO) $)_{2}$ and FC6-HC4 (Figure S1) increased $W_{0}$ max by only 3 compared with the value for each surfactant at $75^{\circ} \mathrm{C}$ and 400 bar, showing a very small synergistic effect ${ }^{21}$.

In earlier studies of surfactant mixtures in conventional solvents, the combination of anionic and cationic surfactants was shown to result in strong synergism in terms of interfacial properties, stability of vesicles, reverse-type molecular assemblies and $\mathrm{W} / \mathrm{O}$ dispersions ${ }^{22,23}$. In these cases, synergism is understood to originate from electrostatic interactions between oppositely charged headgroups. These cationic:anionic surfactant mixtures have been simplified further still, by synthesizing pure catanionic surfactants excluding the counterions. ${ }^{24}$

A previous study reported synthesis of three pure catanionic surfactants $\left(\left[\mathrm{C}_{6} \mathrm{~F}_{13} \mathrm{mim}\right]\left[\left(\mathrm{CF}_{3}\right)_{3} \mathrm{~S}\right]\right.$, $\left[\mathrm{C}_{6} \mathrm{~F}_{13} \mathrm{mim}\right]\left[\mathrm{C}_{6} \mathrm{~F}_{13} \mathrm{~S}\right]$ and $\left[\mathrm{C}_{5} \mathrm{~F}_{11} \mathrm{mim}\right]\left[\mathrm{C}_{5} \mathrm{~F}_{11} \mathrm{~S}\right]$, Figure 1) bearing environmentally-acceptable short chain FC tails, and studied formation and properties of $\mathrm{W} / \mathrm{CO}_{2} \mu \mathrm{Es} .{ }^{25}$ One of the these surfactants, namely $\left[\mathrm{C}_{6} \mathrm{~F}_{13} \mathrm{mim}\right]\left[\mathrm{C}_{6} \mathrm{~F}_{13} \mathrm{~S}\right]$, showed exceptional water-solubilizing power $\left(W_{0}{ }^{\max }=\sim 50\right)$, representing the first observation of surfactant synergism in $\mathrm{W} / \mathrm{CO}_{2} \mu \mathrm{Es}$. The catanionic surfactants were shown to display cloud point temperatures, rather than Kraft temperatures, suggesting the catanionic headgroup has some nonionic character ${ }^{25}$.

To clarify the mechanism of synergism and ion pairing with these $\mathrm{CO}_{2}$-active catanionic surfactants this study investigates phase behavior, solubilizing properties and self-assembly structure of $\mathrm{W} / \mathrm{CO}_{2} \mu$ Es at different pressures and $W_{0}$ values. Probe dye studies, using UV-vis absorption spectra with an ionic dye methyl orange was used to follow water uptake and high-pressure small-angle neutron scattering (HP-SANS) was used to determine microemulsion water droplet structures and sizes. The 
SANS measurements have permitted an assessment of the effective packing parameter (EPP, in other words, an intrinsic packing parameter relevant to an individual mixed system under certain experimental conditions $)^{26-29}$ to be made. The EPP is a key index, indicating the preferred self-assembly structure, and is based on surfactant spatial packing, resulting from interactions with solvents (water and $\mathrm{CO}_{2}$ ) and neighboring surfactant molecules. These results demonstrate that catanionic surfactants can offer new insight into the design criteria for inexpensive and environmental-friendly surfactants for $\mathrm{W} / \mathrm{CO}_{2} \mu \mathrm{Es}$ appropriate for industrial use.

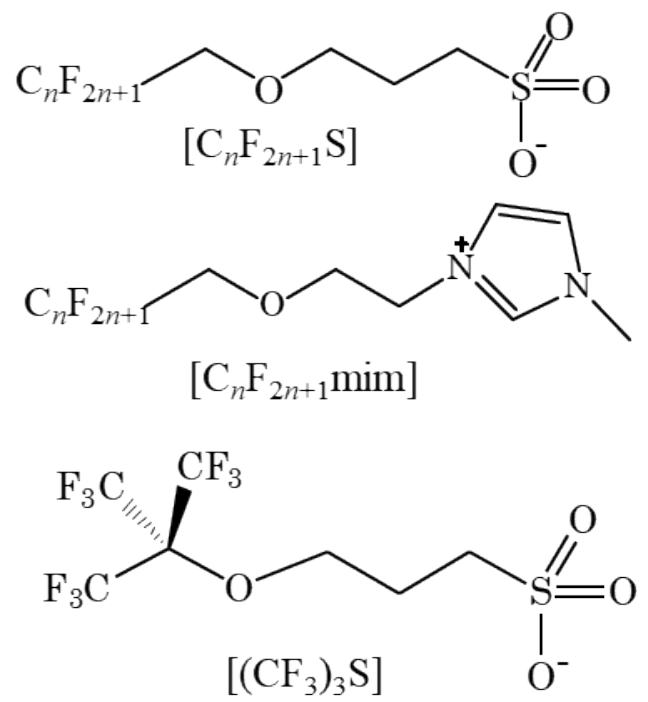

Figure 1 Chemical structures of surfactant ions ( $n=5$ or 6$)$. 


\section{Experimental Section}

\section{Materials}

The catanionic surfactants $\left[\mathrm{C}_{6} \mathrm{~F}_{13} \mathrm{mim}\right]\left[\left(\mathrm{CF}_{3}\right)_{3} \mathrm{~S}\right],\left[\mathrm{C}_{6} \mathrm{~F}_{13} \mathrm{mim}\right]\left[\mathrm{C}_{6} \mathrm{~F}_{13} \mathrm{~S}\right]$ and $\left[\mathrm{C}_{5} \mathrm{~F}_{11} \mathrm{mim}\right]\left[\mathrm{C}_{5} \mathrm{~F}_{11} \mathrm{~S}\right]$

(Figure 1, purity $>95 \%$ ) used here were synthesized and purified as described in a previous study ${ }^{25}$. Ultrapure water with a resistivity of $18.2 \mathrm{M} \Omega \mathrm{cm}$ was obtained from a Millipore Milli-Q Plus system. $\mathrm{CO}_{2}$ was of $99.99 \%$ purity (Ekika Carbon Dioxide Co., Ltd.). Methyl orange was purchased from Acros organics and used without further purification.

\section{Phase behavior observations and UV-visible absorption spectroscopy}

A high-pressure (HP) cell with a metal-to-glass sealed glass window (KP-308-3, Nihon Klingage co., ltd) and a moveable piston inside the cell was employed to examine the phase behaviour of surfactant/water/ $\mathrm{scCO}_{2}$ mixtures by operating pressure and temperature. A detailed description of the experimental apparatus and procedures is given in earlier papers. ${ }^{12,13,25}$

Uptake of water into $\mathrm{W} / \mathrm{CO}_{2} \mu \mathrm{Es}$ was examined by UV-visible absorption spectroscopy measurements in a pressure cell (stainless steel SUS316: cell volume $1.5 \mathrm{~cm}^{3}$ ) with three quartz windows (thickness: $8 \mathrm{~mm}$, inner diameter: $10 \mathrm{~mm}$ ). The spectral measurements were performed with a doublebeam spectrophotometer (Hitachi High-Technologies, Co., U-2810). Each window was positioned to provide a perpendicular $10-\mathrm{mm}$ optical path. The windows were attached and fastened tightly to the stainless steel body of the cell with PTFE kel-F packing, thereby compressing the packing between the stainless steel parts and the windows, providing excellent sealing (tested up to 400 bar); temperature was controlled by circulating water thermostat bath.

The spectroscopic measurements of the water/surfactant $/ \mathrm{scCO}_{2}$ systems were performed at 350 bar and 45 or $75^{\circ} \mathrm{C}$. The densities of $\mathrm{CO}_{2}$ were calculated using the Span-Wagner equation of state (EOS) ${ }^{30}$. Pre-determined amounts of surfactant and $\mathrm{CO}_{2}$, where the molar ratio of surfactant to $\mathrm{CO}_{2}$ was fixed at $8 \times 10^{-4}$, were loaded into the optical cell. An aqueous solution containing methyl orange (MO) as a 
trace marker dye $(3 \mathrm{mM})$ was then added into the optical cell through a six-port valve until the clear single-phase Winsor-IV $\mathrm{W} / \mathrm{CO}_{2} \mu \mathrm{E}$ microemulsion converted into a turbid emulsion or hydrated surfactant was seen to precipitate. During spectroscopic measurements, the $\mathrm{scCO}_{2}$ mixtures were stirred by a magnetic stirrer.

\section{High-Pressure small-angle neutron scattering (SANS) measurements and data analyses}

Due to the range of neutron wavelengths available, time-of-flight (T-O-F) SANS is suitable for studying the shapes and sizes of colloidal systems. High-pressure SANS (HP-SANS) is a particularly important technique for determining aggregated nanostructures in supercritical $\mathrm{CO}_{2}{ }^{10,12,13,25}$. The HPSANS measurements were performed at $45^{\circ} \mathrm{C}$ at various pressures using the SANS2D T-O-F instrument, at the Rutherford Appleton Laboratory at ISIS UK, in conjunction with a stirred, high-pressure cell (Thar). The cell path length and the incident neutron beam diameter were both $10 \mathrm{~mm}$. The measurements gave absolute scattering cross sections $I(Q)\left(\mathrm{cm}^{-1}\right)$ as a function of momentum transfer $Q\left(\AA^{-1}\right)$, which is defined as $Q=(4 \pi / \lambda) \sin (\theta / 2)$, where $\theta$ is the scattering angle. The accessible $Q$ range was $0.002-1.0 \AA^{-1}$ on SANS2D arising from a white neutron beam with incident wavelengths, $\lambda$, of $2.2-10 \AA$. The data were normalized for transmission, empty cell, solvent background, and pressure induced changes in cell volume as before ${ }^{12,13,25}$.

Pre-determined amounts of $\mathrm{D}_{2} \mathrm{O}$ and surfactant, where the molar ratio of surfactant to $\mathrm{CO}_{2}$ was fixed at $8.0 \times 10^{-4}(=16.7 \mathrm{mM}$ at the appropriate experimental condition), were loaded into the Thar cell. Then $\mathrm{CO}_{2}(11.3 \mathrm{~g})$ was introduced into the cell by using a high-pressure pump, and the surfactant $/ \mathrm{D}_{2} \mathrm{O} / \mathrm{CO}_{2}$ mixture was pressurized to 120,200 or 350 bar at $45^{\circ} \mathrm{C}$ by decreasing the inner volume of the cell. Under vigorous stirring, visual observations were carried out to identify the mixture as being a transparent single-phase $\left(\mathrm{W} / \mathrm{CO}_{2} \mu \mathrm{E}\right)$ or a turbid phase. Finally, the HP-SANS experiments were performed for not only single-phase $\mathrm{W} / \mathrm{CO}_{2} \mu \mathrm{Es}$, but also turbid phases formed below the cloud point phase transition pressure $P_{\text {trans. }}$ Due to the systems being dilute dispersions (volume fractions typically $\leq$ 
0.012), the physical properties of the continuous phase of $\mathrm{scCO}_{2}$ were assumed to be equivalent to those of pure $\mathrm{CO}_{2}$. The scattering length density (SLD) of reversed micelle shells $\left(\rho_{\text {shell }}\right)$ was calculated as $\rho_{\text {shell }}$ $=2.28 \times 10^{10} \mathrm{~cm}^{-2}$. The SLDs of $\mathrm{CO}_{2}\left(\rho_{\mathrm{CO} 2}\right)$ and aqueous cores $\left(\rho_{\text {core }}\right)$ containing the catanionic headgroup in the $\mathrm{D}_{2} \mathrm{O} / \mathrm{CO}_{2} \mu \mathrm{E}$ are variables of $\mathrm{CO}_{2}$ density and $W_{0}$, and are estimated as; $\rho_{\mathrm{CO} 2} /\left(10^{10} \mathrm{~cm}^{-2}\right)=2.29$ at 350 bar, 2.03 at 200 bar, and 1.64 at 120 bar, and $\rho_{\text {core }} /\left(10^{10} \mathrm{~cm}^{-2}\right)=3.34$ at $W_{0}=5,4.15$ at $W_{0}=10,4.62$ at $W_{0}=15,4.92$ at $W_{0}=20,5.13$ at $W_{0}=25,5.28$ at $W_{0}=30$ and 5.40 at $W_{0}=35$ as estimated in supporting information (see $\mathbf{S 2}$ ). As $\rho_{\text {shell }}$ was close to $\rho_{\mathrm{CO} 2}$ and the shells are solvated with $\mathrm{CO}_{2}$, neutron scattering from the shells was assumed to be negligible owing to the small contrast step. Therefore, SANS from the $\mathrm{D}_{2} \mathrm{O} / \mathrm{CO}_{2} \mu \mathrm{Es}$ was assumed to only be from the so-called aqueous core contrast. For model fitting data analysis, the $\mathrm{W} / \mathrm{CO}_{2} \mu \mathrm{E}$ droplets were treated as ellipsoidal particles with a Schultz distribution in core radii ${ }^{31}$. The polydispersities in ellipsoid radii were fixed at 0.3 as found in spherical $\mathrm{D}_{2} \mathrm{O} / \mathrm{CO}_{2} \mu$ Es with the double FC-tail surfactants (polydispersity $=0.17-0.40)^{12,13,25}$. Full accounts of the scattering laws are given elsewhere $12,13,25,32$. Data have been fitted to the models described above using the SasView smallangle scattering analysis software package (http://www.sasview.org/) $12,13,25,32$. The fitted parameters are the core radii perpendicular to the rotation axis $\left(R_{\mathrm{f}-\mathrm{ell}, \mathrm{a}}\right)$ and along the rotation axis $\left(R_{\mathrm{f}-\mathrm{ell}, \mathrm{b}}\right)$ for ellipsoidal particles; prior to full model fitting micellar dimensions were initially estimated by Guinier analysis $\left(R_{\mathrm{g}-}\right.$ sph) ${ }^{33}$. The catanionic reverse micelles have $\mathrm{C}_{6}$-perfluorocarbon tails shells, which weakly interact with other $^{25}$. The hard sphere model was employed as an effective $\mathrm{S}(Q)$ for all $W_{0}$ values. 


\section{Results and Discussion}

\section{Aggregation behavior of catanionic surfactant reverse micelles in water/supercritical $\mathrm{CO}_{2}$ mixtures}

In a previous study, visual observation and FT-IR spectra measurements for $16.7 \mathrm{mM}$ $\left[\mathrm{C}_{6} \mathrm{~F}_{13} \mathrm{mim}\right]\left[\mathrm{C}_{6} \mathrm{~F}_{13} \mathrm{~S}\right] / \mathrm{W} / \mathrm{CO}_{2} \mu \mathrm{Es}$ were conducted. ${ }^{25}$ Those results showed formation of transparent single-phases $\mathrm{W} / \mathrm{CO}_{2} \mu \mathrm{E}$ at pressures above $P_{\text {trans }}$ in Fig. S2, and absorbance characteristic of hydrogen bonded water increased with loading water over the $W_{0}$ range from 0 to 50 at $45^{\circ} \mathrm{C}$ and 350 bar, suggesting a high water-solubilizing power of $W_{0} \max =50 .{ }^{25}$ Here, to confirm this observation, solubilization of water and the tracer ionic dye (aqueous methyl orange $\mathrm{MO} 3 \mathrm{mM}$ ) by $\left[\mathrm{C}_{6} \mathrm{~F}_{13} \mathrm{mim}\right]\left[\mathrm{C}_{6} \mathrm{~F}_{13} \mathrm{~S}\right]$ reverse micelles was examined. The dye solution was loaded into $16.7 \mathrm{mM}$ catanionic surfactant $/ \mathrm{CO}_{2}$ mixtures, and the UVvis adsorption spectra were measured at different $W_{0}$ values. Alone, $\mathrm{MO}$ does not dissolve in pure $\mathrm{CO}_{2}$ but it does dissolve in water, and is generally incorporated within the water-rich pockets of single-phase $\mathrm{W} / \mathrm{CO}_{2} \mu$ Es, dyeing the systems red. ${ }^{12,13}$ The surfactant $\left[\mathrm{C}_{6} \mathrm{~F}_{13} \mathrm{mim}\right]\left[\mathrm{C}_{6} \mathrm{~F}_{13} \mathrm{~S}\right]$ formed transparent and reddish single-phase $\mathrm{CO}_{2}$ systems with the $\mathrm{MO}$ solution, however, the other catanionic surfactants always remained as precipitates, yielding undyed $\mathrm{CO}_{2}$ phases.

The UV-vis spectra of $\mathrm{MO}$ for $\left[\mathrm{C}_{6} \mathrm{~F}_{13} \mathrm{mim}\right]\left[\mathrm{C}_{6} \mathrm{~F}_{13} \mathrm{~S}\right]$ and the other catanionic surfactants are displayed in Figures 2 and S3 (supporting information), respectively. At $45^{\circ} \mathrm{C}$ the spectra showed large and broad absorption peaks of $\mathrm{MO}$, and an absorbance maximum $\left(\lambda_{\max }\right)$ at $\sim 418 \mathrm{~nm}$ independent of $W_{0}$. As $\lambda_{\max }$ is known to shift to longer wavelengths ${ }^{12,13}$ when MO molecules are solubilized in more polar environments, hence $\lambda_{\max }$ can be employed to gauge microenvironment polarity. Previous experiments with $\mathrm{W} / \mathrm{CO}_{2} \mu \mathrm{Es}$ with anionic hybrid surfactants FC6-HCn and double FC-tail surfactants $n \mathrm{FG}(\mathrm{EO})_{2}$ and $n \mathrm{FS}(\mathrm{EO})_{2}$ displayed $\lambda_{\max }$ values at $\sim 420 \mathrm{~nm}$ even at different $W_{0}$ values and temperatures of 45 and 75 ${ }^{\circ} \mathrm{C},{ }^{12,13}$ consistent with free MO molecules solubilized in the aqueous cores. The similar $\lambda_{\max }$ values for anionic and catanionic surfactants imply that the microenvironmental polarity surrounding MO molecules was essentially unaffected by the different kinds of headgroups, most likely as a result of weak interactions between headgroups and MO molecules. 


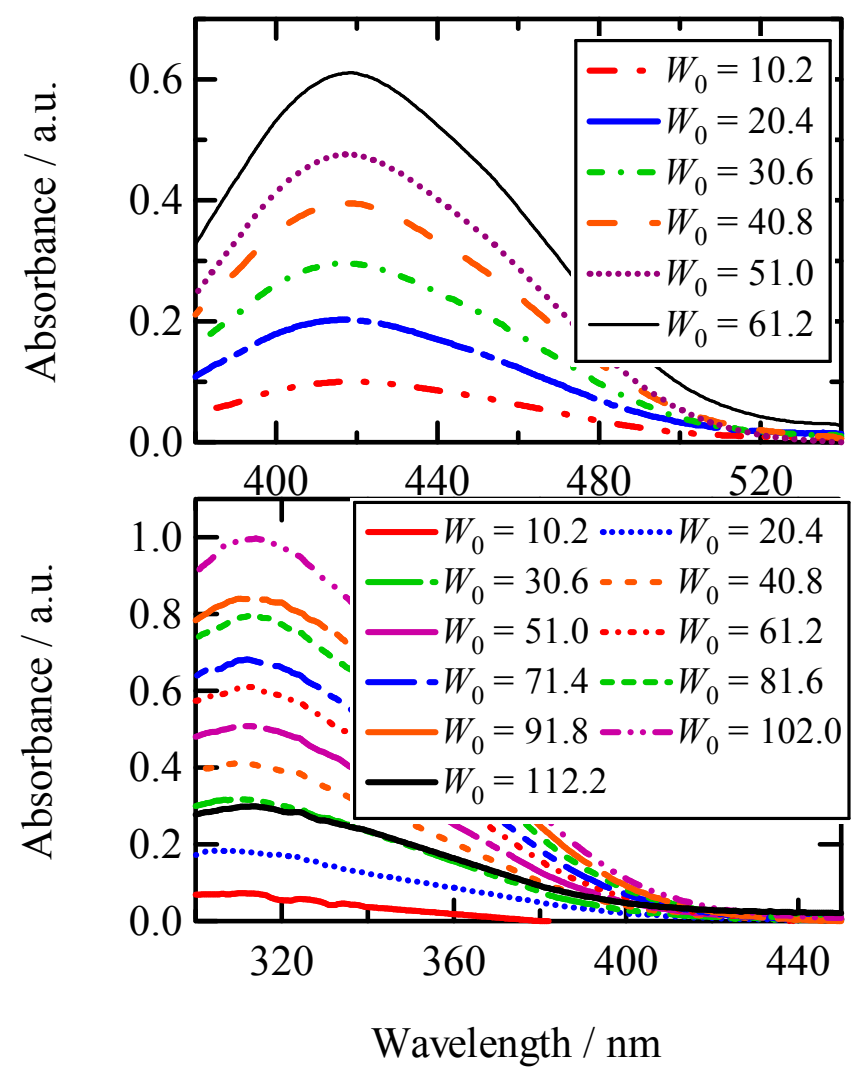

Figure $2 \mathrm{UV}$-vis spectra of $16.7 \mathrm{mM}\left[\mathrm{C}_{6} \mathrm{~F}_{13} \mathrm{mim}\right]\left[\mathrm{C}_{6} \mathrm{~F}_{13} \mathrm{~S}\right] /$ water $/ \mathrm{CO}_{2}$ mixtures with different $W_{0}$ values at 350 bar and $45{ }^{\circ} \mathrm{C}$ (Top) or $75^{\circ} \mathrm{C}$ (bottom). $3 \mathrm{mM}$ methyl orange aqueous solution was loaded as a dispersed aqueous phase.

Interestingly, the $\lambda_{\max }$ values blue-shifted to $\sim 314 \mathrm{~nm}$ elevating temperature from $45^{\circ} \mathrm{C}$ to $75^{\circ} \mathrm{C}$, suggesting a notable change in microenvironment. Such blue shifts with MO have been reported in studies in $\mathrm{MO} /$ catanionic surfactant/water mixtures, explained by generation of ion pair complexes of $\mathrm{MO}$ and cationic surfactants. ${ }^{34}$ This suggests that at the high temperature cation-anion dissociation of the catanionic surfactant promoted and then formed anionic $\mathrm{MO}$-cationic $\left[\mathrm{C}_{6} \mathrm{~F}_{13} \mathrm{mim}\right]$ ion pair complexes.

As shown in Figure 2, the adsorption peaks grew on increasing the dosing of MO solution and the systems remained transparent. To determine the maximum water solubilization $\left(W_{0}^{\max }\right)$ of the surfactant at each temperature, the maximum absorbance was plotted as a function of $W_{0}$ as shown in Figure S4. 
The linear behavior seen over the $W_{0}$ ranges of $0-61.2$ at $45^{\circ} \mathrm{C}$ and of $0-102$ at $75^{\circ} \mathrm{C}$ is consistent with $W_{0}{ }^{\max }$ values to be $\sim 60$ and $\sim 100$, respectively. The $W_{0}{ }^{\max }$ value at $45^{\circ} \mathrm{C}$ was in line with results from FTIR spectroscopy in a previous study $\left(W_{0}{ }^{\max }=\sim 50\right)^{25}$. Such a high value for $W_{0}{ }^{\max }$ over 50 is quite rare and can be identified with a highly efficient surfactant for stabilizing $\mathrm{W} / \mathrm{CO}_{2}$ microemulsions. On the other hand, no $\mathrm{MO}$ absorption was observed for the catanionic surfactants $\left[\mathrm{C}_{6} \mathrm{~F}_{13} \mathrm{mim}\right]\left[\left(\mathrm{CF}_{3}\right)_{3} \mathrm{~S}\right]$ and $\left[\mathrm{C}_{5} \mathrm{~F}_{11} \mathrm{mim}\right]\left[\mathrm{C}_{5} \mathrm{~F}_{11} \mathrm{~S}\right]$ (Figure $\mathbf{S 3}$ ), suggesting that droplet $\mathrm{W} / \mathrm{CO}_{2} \mu \mathrm{Es}$, do not form. Since the constituent surfactants of these catanionic surfactants are insoluble and unable to stabilize $\mathrm{W} / \mathrm{CO}_{2} \mu \mathrm{Es},{ }^{25}$ the synergistic effect of pairing of surfactant anions and cations has been clearly demonstrated by the formation of $\left[\mathrm{C}_{6} \mathrm{~F}_{13} \mathrm{mim}\right]\left[\mathrm{C}_{6} \mathrm{~F}_{13} \mathrm{~S}\right] / \mathrm{W} / \mathrm{CO}_{2}$ microemulsions, which have notably enhanced stability at 75 ${ }^{\circ} \mathrm{C}$.

An important question remaining from the previous study 25 is "why does only $\left[\mathrm{C}_{6} \mathrm{~F}_{13} \operatorname{mim}\right]\left[\mathrm{C}_{6} \mathrm{~F}_{13} \mathrm{~S}\right]$ stabilize $\mathrm{W} / \mathrm{CO}_{2} \mu \mathrm{Es}$, whereas the other surfactants do not?'. The structural differences between $\left[\mathrm{C}_{6} \mathrm{~F}_{13} \mathrm{mim}\right]\left[\left(\mathrm{CF}_{3}\right)_{3} \mathrm{~S}\right],\left[\mathrm{C}_{6} \mathrm{~F}_{13} \mathrm{mim}\right]\left[\mathrm{C}_{6} \mathrm{~F}_{13} \mathrm{~S}\right]$ and $\left[\mathrm{C}_{5} \mathrm{~F}_{11} \mathrm{mim}\right]\left[\mathrm{C}_{5} \mathrm{~F}_{11} \mathrm{~S}\right]$ are small, with just two more $\mathrm{CF}_{2}$ units for $\left[\mathrm{C}_{6} \mathrm{~F}_{13} \mathrm{mim}\right]\left[\mathrm{C}_{6} \mathrm{~F}_{13} \mathrm{~S}\right]$ than the others. Based on previous studies ${ }^{7,12,13,32}$ the longer double FC-tails in $\left[\mathrm{C}_{6} \mathrm{~F}_{13} \mathrm{mim}\right]\left[\mathrm{C}_{6} \mathrm{~F}_{13} \mathrm{~S}\right]$ would be expected to lead to higher $\mathrm{CO}_{2}$-philicity and a greater solubility in $\mathrm{scCO}_{2}$. It seems that the total fluorination is important, and for this class of surfactants there is a critical number of 12 fluorinated carbons needed for stabilization of microemulsions. In other words, surfactants must (1) be sufficiently compatible (soluble) in $\mathrm{scCO}_{2}$ to adsorb strongly at the water$\mathrm{CO}_{2}$ interface and (2) have sufficiently thick FC-shells to maintain droplet stability. These phase behavior studies indicate that $\left[\mathrm{C}_{6} \mathrm{~F}_{13} \mathrm{mim}\right]\left[\mathrm{C}_{6} \mathrm{~F}_{13} \mathrm{~S}\right]$ is an optimized surfactant for stabilizing $\mathrm{W} / \mathrm{CO}_{2} \mu$ Es with high water loadings over $W_{0}^{\max }>50$. Furthermore, despite the different catanionic structure, this twin-tailed surfactant is comparable to other super-efficient $\mathrm{CO}_{2}$-philic surfactants $8 \mathrm{FG}(\mathrm{EO})_{2}$ and FC6-HC4 which instead bear two tails covalently bound to the anionic headgroup 7,12,13,32. 


\section{Nano-structure of the catanionic surfactant $/ \mathrm{W} / \mathrm{CO}_{2}$ microemulsions}

A previous study of $\left[\mathrm{C}_{6} \mathrm{~F}_{13} \mathrm{mim}\right]\left[\mathrm{C}_{6} \mathrm{~F}_{13} \mathrm{~S}\right] / \mathrm{W} / \mathrm{CO}_{2} \mu$ Es with $W_{0}=10$ at 350 bar and $45^{\circ} \mathrm{C}{ }^{25}$, the SANS profiles were showed the HP-SANS profiles to be consistent with an ellipsoidal form factor model. To clarify changes in the core nanostructure with $W_{0}$ and pressure, SANS $I(Q)$ profiles were measured at $45^{\circ} \mathrm{C}, W_{0}=5-35$ and $P=120-350$ bar. SANS data along with the fitted $I(Q)$ functions are shown in Figure 3 (or Figure S5). The SANS profiles of $\left[\mathrm{C}_{6} \mathrm{~F}_{13} \mathrm{mim}\right]\left[\mathrm{C}_{6} \mathrm{~F}_{13} \mathrm{~S}\right] / \mathrm{D}_{2} \mathrm{O} / \mathrm{CO}_{2}$ mixtures with $W_{0} \leq 20-25$ at 200350 bar and $\leq 10$ at 120 bar show a gradient of $\sim 0$ for the $\log [I(Q)]-\log Q$ plot at $Q<0.03 \AA^{-1}$, suggesting formation of globular nanosized $\mathrm{D}_{2} \mathrm{O}$ cores. All SANS data were always measured under stirring. On the other hand, when $W_{0}$ was $\geq 25$ at 200-350 bar the scattering intensity increased with decreasing $Q$ at $Q<$ $0.02 \AA^{-1}$. displaying gradients of $\sim Q^{-4}$. At high $W_{0}$ values $\geq 25$ separated water probably remained in the systems, and was dispersed as equilibrium $\mathrm{W} / \mathrm{CO}_{2}$ emulsion droplets owing to the stirring $\mathrm{W} / \mathrm{CO}_{2} \mu \mathrm{Es}$. The SANS also showed gradients of $\sim Q^{-4}$ at $Q<0.02 \AA^{-1}$.

As a first step in SANS data analysis, Guinier ${ }^{33}$ and Porod ${ }^{35}$ plots were used to estimate the $\mathrm{D}_{2} \mathrm{O}$ core radii (Figures S6 and S7), and the results are listed in Table S1. The Porod plot asymptote at high $Q$ can be used to analyze interfacial area per surfactant molecule ${ }^{35}$. Unfortunately, reliable asymptotic $\left\{\mathrm{I}(Q) Q^{4}\right\}_{Q \rightarrow \infty}$ values could not be obtained due to a combination of weak scattering and background noise as shown in Figure S7. SANS data were also analyzed with Ornstein-Zernicke formalism to investigate density fluctuations in a system approaching critical demixing or phase separation. ${ }^{36-38}$ The correlation lengths $\xi$, showing sizes characteristic of such structural domains are plotted as a function of $W_{0}$ in Figure S9. The $\xi$ values were found to increase from $\sim 12 \AA$ to $\sim 30 \AA$ with increasing $W_{0}$ from 10 to 35 and the increasing trends of $\xi$ were similar to those radii obtained from Porod $\left(R_{\mathrm{p} \text {-sph }}\right)$ and form fitting analysis

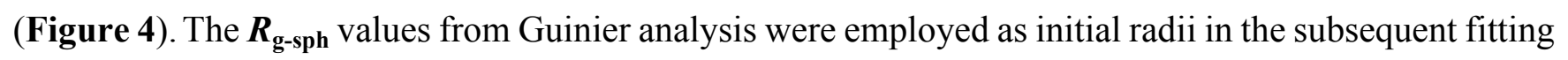
using models for polydisperse Schultz spherical or ellipsoidal particles, as appropriate for giving the best fits. In the case of ellipsoids, both oblate and prolate aspect ratios were compared (Figure S5), and the prolate model gave better fits. 

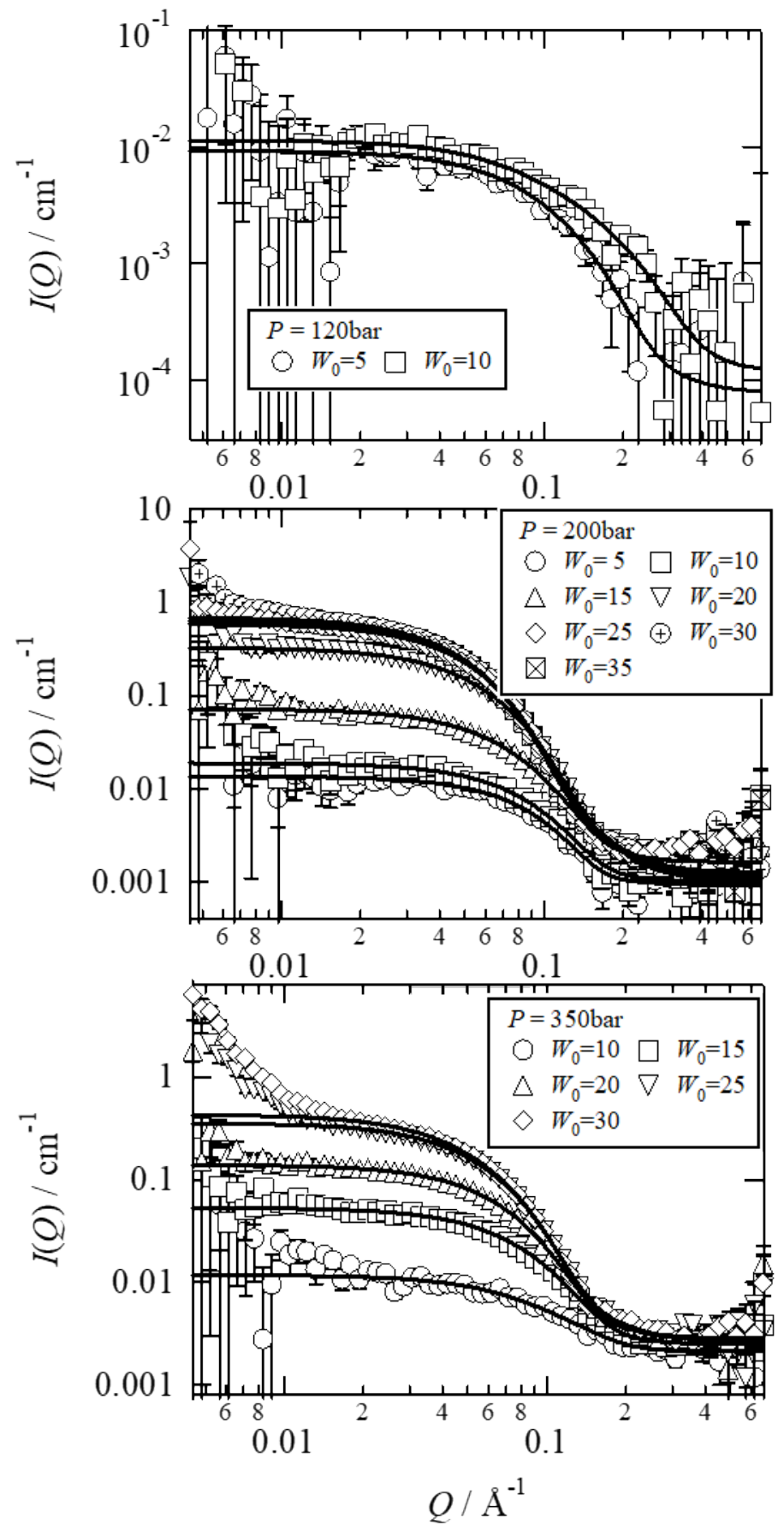

Figure 3. SANS profiles of $\mathrm{D}_{2} \mathrm{O} / \mathrm{CO}_{2} \mu \mathrm{E}$ with $16.7 \mathrm{mM}\left[\mathrm{C}_{6} \mathrm{~F}_{13}\right.$ mim $]\left[\mathrm{C}_{6} \mathrm{~F}_{13} \mathrm{~S}\right]$ with different $W_{0}$ values at $45^{\circ} \mathrm{C}$ and 120-350 bar. Solid lines are theoretical curves of prolate ellipsoid particle model fitted to the experimental data. 
The model fit parameters for the prolate $\mathrm{D}_{2} \mathrm{O}$ core $\mu \mathrm{E}$ droplets $\left(R_{\mathrm{f}-\mathrm{ell}, \mathrm{a}}\right.$ and $\left.R_{\mathrm{f}-\mathrm{ell}, \mathrm{b}}\right)$ are listed in Table S3. To demonstrate droplet growth with increased loading water, equatorial $\left(R_{\text {ell-a }}\right)$ and polar $\left(R_{\text {ell-b }}\right)$ radii of prolate $\mathrm{D}_{2} \mathrm{O}$ cores are plotted in Figure 4 as a function of $W_{0}$ at pressures $\geq 200$ bar.

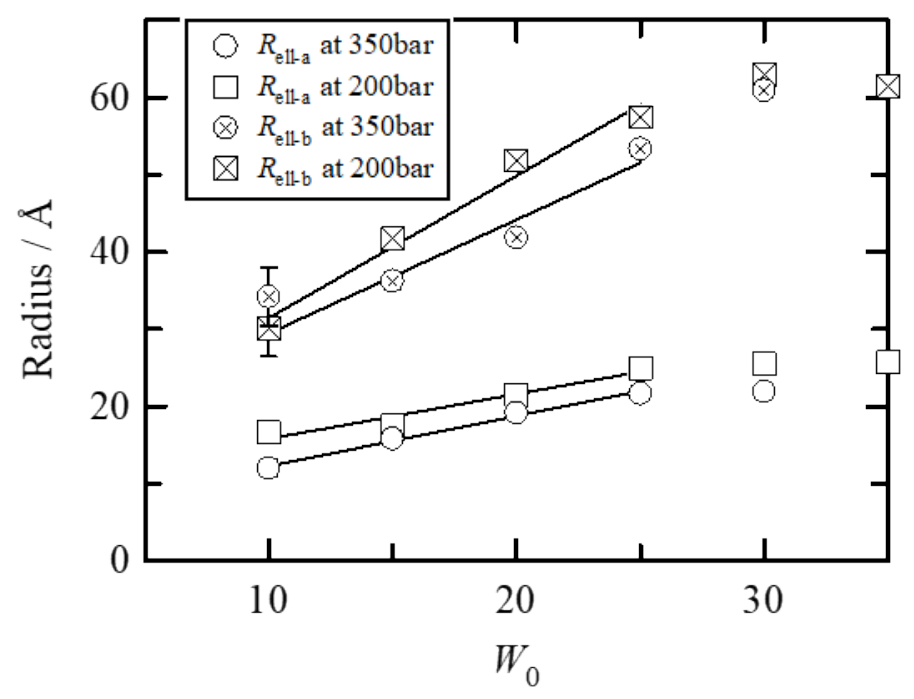

Figure 4. Change in prolate ellipsoid radii $\left(R_{\text {ell-a }}\right.$ and $\left.R_{\text {ell-b }}\right)$ for $16.7 \mathrm{mM}\left[\mathrm{C}_{6} \mathrm{~F}_{13} \mathrm{mim}\right]\left[\mathrm{C}_{6} \mathrm{~F}_{13} \mathrm{~S}\right] / \mathrm{D}_{2} \mathrm{O} / \mathrm{CO}_{2}$ $\mu \mathrm{E}$ cores as a function of $W_{0}$ at $45^{\circ} \mathrm{C}$ and 200 bar or 350 bar.

As seen in Table $\mathbf{S 3}$ at 120 bar the radii reduced with increasing $W_{0}$ from 5 to 10 , which was accompanied by a phase transition from transparent $\mu$ Es to turbid phases (i.e. Winsor IV $\rightarrow$ stirred Winsor II $\mathrm{W} / \mathrm{CO}_{2}$ microemulsions). On the other hand, at pressures $\geq 200 \mathrm{bar}$, the oblate radii increased linearly with $W_{0}$ as up to $W_{0}=25$, being described by $\left(R_{\text {ell-a }} / \AA\right)=\boldsymbol{a}_{\text {ell-a }}+\boldsymbol{b}_{\text {ell-a }} W_{0}$ and $\left(R_{\text {ell-b }} / \AA\right)=\boldsymbol{a}_{\text {ell-b }}+\boldsymbol{b}_{\text {ell-b }} W_{0}$ (where $\boldsymbol{a}_{\mathrm{ell}-\mathrm{a}}, \boldsymbol{b}_{\mathrm{ell}-\mathrm{a}}, \boldsymbol{a}_{\mathrm{ell}-\mathrm{b}}, \boldsymbol{b}_{\mathrm{ell-b}}=10.0,0.58,13.0,1.84$ at 200 bar, and 5.79, 0.65, 14.7, 1.47 at 350 bar. Eventually, the radii reached $R_{\text {ell-a }}=\sim 26 \AA$ and $R_{\text {ell-b }}=\sim 63 \AA$ at 200 bar, and $R_{\text {ell-a }}=\sim 22 \AA$ and $R_{\text {ell-b }}=$ $\sim 61 \AA$ at 350 bar. This is consistent with swelling behavior with loading water as commonly reported in $\mathrm{W} / \mathrm{O}$ and $\mathrm{W} / \mathrm{CO}_{2}$ reverse microemulsions ${ }^{13,32,39}$. The radii values seemed to plateau for $W_{0}>30$ and visually these systems were turbid, consistent with stirred separating Winsor II phases. The slight discrepancies with $W_{0}{ }^{\max }$ obtained by spectroscopically may be due to weak stirring power in the pressure 
cell and/or use of $\mathrm{D}_{2} \mathrm{O}$ instead of $\mathrm{H}_{2} \mathrm{O}$ needed for the HP-SANS experiments. In contrast with the increasing trend of radii with $W_{0}$, the aspect ratios $\left(R_{\text {ell-b }} / R_{\text {ell-a }}\right)$ were very similar (1.8-2.9) and seemed to be independent of pressure and $W_{0}$ as shown in Figure S10. The formation of elongated reverse micelles is an interesting observation, and is expected to increase $\mathrm{CO}_{2}$ viscosity, which may find applications in $\mathrm{CO}_{2}$-EOR efficiency ${ }^{13,40,41}$. Using equations (S4) and (S5) in supporting information (Sec S9), apparent intrinsic and specific viscosities, $[\eta]$ and $\eta_{\mathrm{sp}}$, were estimated (Table S3). The viscosity enhancements predicted this way would only be modest, $\sim 13 \%$ or less compared with that of pure $\mathrm{CO}_{2}$. Hence, higher surfactant concentration could be needed to promote higher $\mathrm{CO}_{2}$ thickening.

Previous SANS studies of double FC-tail surfactants $n \mathrm{FG}(\mathrm{EO})_{2}$ with different FC lengths $(n=4$ 8) also found a linear relationship between spherical $\mathrm{D}_{2} \mathrm{O}$ core radius, $R_{\mathrm{c}}$, and $W_{0}$ where $R_{\mathrm{c}}=\boldsymbol{a}+\boldsymbol{b} W_{0}$, and the constants $\boldsymbol{a}=5.0-5.4$ and $\boldsymbol{b}=0.60-0.64^{32}$. The average values $\boldsymbol{a}$ and $\boldsymbol{b}$ of prolate core radii for $\left[\mathrm{C}_{6} \mathrm{~F}_{13} \mathrm{mim}\right]\left[\mathrm{C}_{6} \mathrm{~F}_{13} \mathrm{~S}\right] / \mathrm{D}_{2} \mathrm{O} / \mathrm{CO}_{2}$ microemulsions, namely $\boldsymbol{a}=\left(2 \boldsymbol{a}_{\text {ell-a }}+\boldsymbol{a}_{\mathrm{ell}-\mathrm{b}}\right) / 3$ and $\boldsymbol{b}=\left(2 \boldsymbol{b}_{\text {ell-a }}+\boldsymbol{b}_{\text {ell-b }}\right) / 3$, were 11.0 and 1.00 at 200 bar and 8.8 and 0.92 at 350 bar, and these are 1.7-2.1 and 1.5-1.6 times larger than those for $n \mathrm{FG}(\mathrm{EO})_{2}$, respectively. For spherical geometry the volume of surfactant headgroup ( $\left.v_{\text {head }}\right)$ and area per surfactant molecule $(A)$, respectively are related by equation (1)

$$
\alpha(p) R_{\mathrm{c}}=\left(3 v_{\text {head }} / A\right)+\left(3 v_{\mathrm{w}} / A\right) W_{0}
$$

where $\alpha(p)=1+2 p^{2}, p$ is polydispersity index $\left(\sigma / R_{\mathrm{c}}\right), R_{\mathrm{c}}$ is the core radius, and $v_{\mathrm{w}}$ is volume of a water molecule ${ }^{13,32}$. It follows that the larger $\boldsymbol{a}$ and $\boldsymbol{b}$ values suggests $\left[\mathrm{C}_{6} \mathrm{~F}_{13} \mathrm{mim}\right]\left[\mathrm{C}_{6} \mathrm{~F}_{13} \mathrm{~S}\right]$ to have a larger $v_{\text {head }}$ and a smaller $A$ than for the $n \mathrm{FG}(\mathrm{EO})_{2}$ series. Based on Equation (1), a volume-to-surface area ratio per aqueous core in reverse $\mu \mathrm{E}\left(v_{\text {core }} / s_{\text {core }}\right)$ can be expressed as,

$$
\alpha(p)\left(v_{\text {core }} / s_{\text {core }}\right)=\left(v_{\text {head }} N_{\text {agg }}+v_{\mathrm{w}} W_{0} N_{\text {agg }}\right) /\left(A N_{\text {agg }}\right)=\left(v_{\text {head }} / A\right)+\left(v_{\mathrm{w}} / A\right) W_{0}
$$

where $N_{\text {agg }}$ is aggregation number. ${ }^{13,32}$ An advantage of using Equation (2) is that it can be applied to a wide range of morphologies (spheres, ellipsoids, rods etc), whereas Equation (1) relates only to spherical morphology. Using equation 2 and assuming constant $v_{\text {head }}$ and $A$ for $\left[\mathrm{C}_{6} \mathrm{~F}_{13} \mathrm{mim}\right]\left[\mathrm{C}_{6} \mathrm{~F}_{13} \mathrm{~S}\right]$, $\left(v_{\text {core }} / s_{\text {core }}\right)$ values calculated from $R_{\text {ell-a }}$ and $R_{\text {ell-b }}$ were plotted as a function of $W_{0}$, as displayed in Figure 5. 


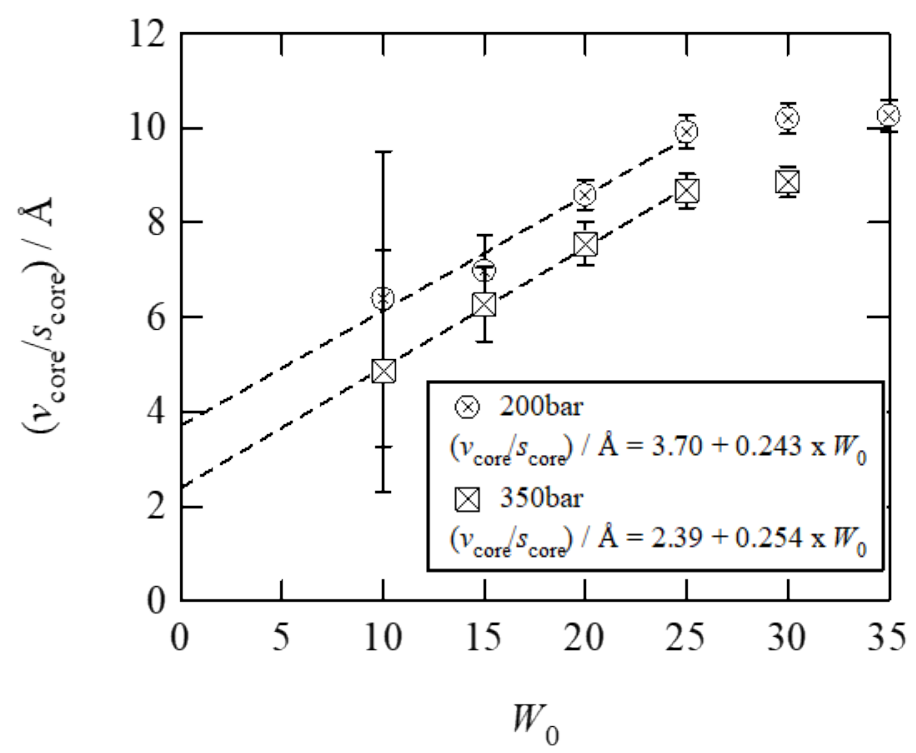

Figure 5. Change in $\left(v_{\text {core }} / s_{\text {core }}\right)$ of prolate cores in $16.7 \mathrm{mM}\left[\mathrm{C}_{6} \mathrm{~F}_{13} \mathrm{mim}\right]\left[\mathrm{C}_{6} \mathrm{~F}_{13} \mathrm{~S}\right] / \mathrm{D}_{2} \mathrm{O} / \mathrm{CO}_{2} \mu$ Es as a function of $W_{0}$ at $45^{\circ} \mathrm{C}$ and 200 bar or 350 bar.

The $\left(v_{\text {core }} / s_{\text {core }}\right)$ data at $W_{0} \leq 25$ were expressed as linear functions, suggesting $v_{\text {head }}$ and $A$ can be calculated using Equation (2). The values of $A, v_{\text {head }}$, and radius of headgroup $\left(R_{\text {head }}=\left(3 v_{\text {head }} / 4 \pi\right)^{1 / 3}\right)$ obtained from the slopes and the intercepts were $\left(A, v_{\text {head }}, R_{\text {head }}\right)=\left(105 \AA^{2}, 459 \AA^{3}, 4.8 \AA\right)$ at 200 bar and $\left(101 \AA^{2}, 284 \AA^{3}, 4.1 \AA\right)$ at 350 bar. At the higher pressures, the headgroup area and volume became smaller, implying a decrease in surfactant cation-anion pair dissociation and/or a decrease in the portion of the head groups immersed in the aqueous cores owing to increased solvation of surfactant tails by $\mathrm{CO}_{2}$ at the higher pressure (density). Therefore, the increased $\mathrm{CO}_{2}$ pressure (or density) affects not only tail$\mathrm{CO}_{2}$ solvation but also interactions between anionic and cationic headgroups. This could lead to a larger EPP and a lower HCB resulting to the smaller $R_{\mathrm{ell}-\mathrm{a}}$ and $R_{\mathrm{ell}-\mathrm{b}}$ (i.e. a larger curvature for smaller droplets) at the higher pressures. As compared with anionic double FC-tail surfactants having a sulfonate group, the $A$ and $v_{\text {head }}$ values of $\left[\mathrm{C}_{6} \mathrm{~F}_{13} \mathrm{mim}\right]\left[\mathrm{C}_{6} \mathrm{~F}_{13} \mathrm{~S}\right]$ at 350 bar are similar to the $n \mathrm{FG}(\mathrm{EO})_{2}$ and $\mathrm{nFS}(\mathrm{EO})_{2}(\mathrm{e} . \mathrm{g}$. $A$ and $v_{\text {head }}$ were $117-129 \AA^{2}$ and $199-231 \AA^{3}$ for the fluorinated surfactants in $\mathrm{W} / \mathrm{CO}_{2} \mu \mathrm{Es}$ at $45^{\circ} \mathrm{C}$ and 350 bar, respectively). This is interesting, because of the very different head group structures comparing 
these two classes of surfactants. The implication is that the high water solubilization capacities of $\left[\mathrm{C}_{6} \mathrm{~F}_{13} \mathrm{mim}\right]\left[\mathrm{C}_{6} \mathrm{~F}_{13} \mathrm{~S}\right]$ in $\mathrm{W} / \mathrm{CO}_{2} \mu$ Es are linked to the electrostatic ion-pairing, promoting larger EPP and lower HCB values comparable to those of the super-efficient double FC-tail surfactants ${ }^{7,12,32}$.

For these $\left[\mathrm{C}_{6} \mathrm{~F}_{13} \mathrm{mim}\right]\left[\mathrm{C}_{6} \mathrm{~F}_{13} \mathrm{~S}\right]$ surfactants in $\mathrm{scCO}_{2}$, the reverse micelle aggregation number $\left(N_{\text {agg }}\right)$ and occupied area per surfactant molecule at the $\mathrm{W} / \mathrm{CO}_{2}$ microemulsion interface $\left(A_{\mathrm{C} / \mathrm{W}}\right)$ were calculated using the following equations.

$$
\begin{aligned}
& N_{\text {agg }}=C_{\text {surf }} / C_{\text {micelle }} \\
& C_{\text {micelle }}=\left(V_{\mathrm{D} 2 \mathrm{O}} C_{\mathrm{D} 2 \mathrm{O}}+V_{\text {head }} C_{\text {surf }}\right) /\left(V_{\text {core }}\right)=C_{\text {surf }}\left(V_{\text {D2O }} W_{0}+v_{\text {head }} N_{\mathrm{A}}\right) /\left(v_{\text {core }} N_{\mathrm{A}}\right) \\
& A_{\mathrm{C} / \mathrm{W}}=s_{\text {core }} / N_{\text {agg }}
\end{aligned}
$$

where $N_{\mathrm{A}}$ is Avogadro's number, $C_{\text {surf }}$ and $C_{\mathrm{D} 2 \mathrm{O}}, C_{\text {micelle }}$ are molar concentrations of surfactant, $\mathrm{D}_{2} \mathrm{O}$ and reverse micelle, $v_{\text {core }}$ is volume per $\mathrm{D}_{2} \mathrm{O}$ core, $V_{\mathrm{D} 2 \mathrm{O}}, V_{\text {head }}$, and $V_{\text {core }}$ are molar volumes of $\mathrm{D}_{2} \mathrm{O}$, surfactant headgroups and $\mathrm{D}_{2} \mathrm{O}$ cores plus headgroups $\left(V_{\text {head }}=v_{\text {head }} N_{\mathrm{A}}, V_{\text {core }}=v_{\text {core }} N_{\mathrm{A}}\right)$, respectively. For the calculation of $A_{\mathrm{C} / \mathrm{W}}$ calculation, $s_{\text {core }}$ is surface area per $\mathrm{D}_{2} \mathrm{O}$ core, being calculated using the ellipsoid radii $\left(R_{\mathrm{f}-\mathrm{ell}, \mathrm{a}}\right.$ and $\left.R_{\mathrm{f}-\mathrm{ell}, \mathrm{b}}\right)$ as well as the calculation of $v_{\text {core }}$ for $C_{\text {micelle. }}$

According to theory ${ }^{26-29}$ the spontaneous packing parameter (SPP) can be obtained by

$$
\mathrm{SPP}=v_{\text {tail }} /\left(A_{0} l_{\text {tail }}\right)
$$

where $v_{\text {tail }}$ and $l_{\text {tail }}$ are hydrophobic tail volume and length, respectively. These symbols have the same meanings as in the expression of the EPP. ${ }^{29}$ Entropy is taken into account by the fact that the area per molecule minimizes the free energy of the surfactant film $\left(A_{0}\right.$ is the area that minimizes the free energy). According to this approach reverse micelles would be obtained with SPP $>1$ (reversed cores form if the surfactant tails orient upward) to $\sim 1$ (cylindrical). In the case of $\mathrm{W} / \mathrm{CO}_{2} \mu \mathrm{Es}$, EPP values should be calculated by taking account of solvation of the head and tail groups with water and $\mathrm{CO}_{2}$ into the $A_{0}$ and $v_{\text {tail }}$ values. If the hydrophobic part is assumed to be a truncated cone, the volume should be ${ }^{13,32}$

$$
v_{\text {tail }}=l_{\text {tail }}\left\{A_{\mathrm{C} / \mathrm{W}}+A_{\text {tail }}+\left(A_{\mathrm{C} / \mathrm{W}} A_{\text {tail }}\right)^{0.5}\right\} / 3
$$

where $A_{\text {tail }}$ is area per hydrophobic tail terminus, respectively. When $A_{0}$ is replaced by $A_{\mathrm{C} / \mathrm{W}}$ for the calculation of EPP in $\mathrm{W} / \mathrm{CO}_{2} \mu \mathrm{Es}$, Eq. (6) can be simply expressed as 


$$
\mathrm{EPP}=\left\{s_{\text {micelle }}+s_{\text {core }}+\left(s_{\text {micelle }} s_{\text {core }}\right)^{0.5}\right\} /\left(3 s_{\text {core }}\right)
$$

where $s_{\text {micelle }}$ is surface area per reverse micelle. In this study, the values of $s_{\text {micelle }}$ were calculated from

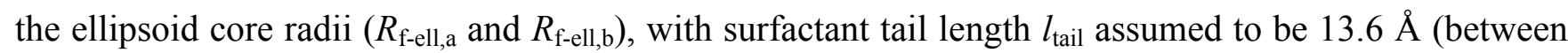
the terminal F-atom and the C-atom bearing the sulfonate group). All the values of $A_{\mathrm{C} / \mathrm{W}}, N_{\text {agg }}$ and EPP obtained by Eqs. (3)-(8) are based on the assumption that all surfactant molecules are adsorbed at the $\mathrm{W} / \mathrm{CO}_{2}$ interface. In actual $\mathrm{W} / \mathrm{CO}_{2} \mu \mathrm{Es}$, it is likely that some surfactant molecules will partition away from the interface. However, this is estimated to be negligible compared with total number of associated surfactant molecules $\left(8.0 \times 10^{-2} \mathrm{~mol} \%\right)$, taking into account very low critical microemulsion concentrations in $\mathrm{scCO}_{2}$ for fluorinated ionic surfactants, which is typically $<10^{-4} \mathrm{~mol} \%{ }^{42}$ The calculated aggregation properties $N_{\mathrm{agg}}, A_{\mathrm{C} / \mathrm{W}}$, and EPP for the prolate droplets are listed in Table $\mathbf{S 4}$. The $A_{\mathrm{C} / \mathrm{W}}$ values were $118-134 \AA^{2}$ at $W_{0}$ values of $10-30$ and are very close to those of $n \mathrm{FG}(\mathrm{EO})_{2}$ and $n \mathrm{FS}(\mathrm{EO})_{2}$ as mentioned above. ${ }^{32}$

Figure 6 shows changes in $N_{\text {agg }}$ and EPP as a function of $W_{0}$ for $\left[\mathrm{C}_{6} \mathrm{~F}_{13} \mathrm{mim}\right]\left[\mathrm{C}_{6} \mathrm{~F}_{13} \mathrm{~S}\right] / \mathrm{D}_{2} \mathrm{O} / \mathrm{CO}_{2}$ microemulsions at $45^{\circ} \mathrm{C}$ and 200 and 350 bar, using data from Table $\mathbf{S 4}$. For comparison purposes, the figures also include literature data for double-tail surfactants $n \mathrm{FG}(\mathrm{EO})_{2}(n=4$ and 8$)$ in $\mathrm{W} / \mathrm{CO}_{2} \mu \mathrm{Es}^{32}$ and the common hydrocarbon surfactant AOT but in $\mathrm{W} / n$-heptane $\mu \mathrm{Es}{ }^{43}$. 


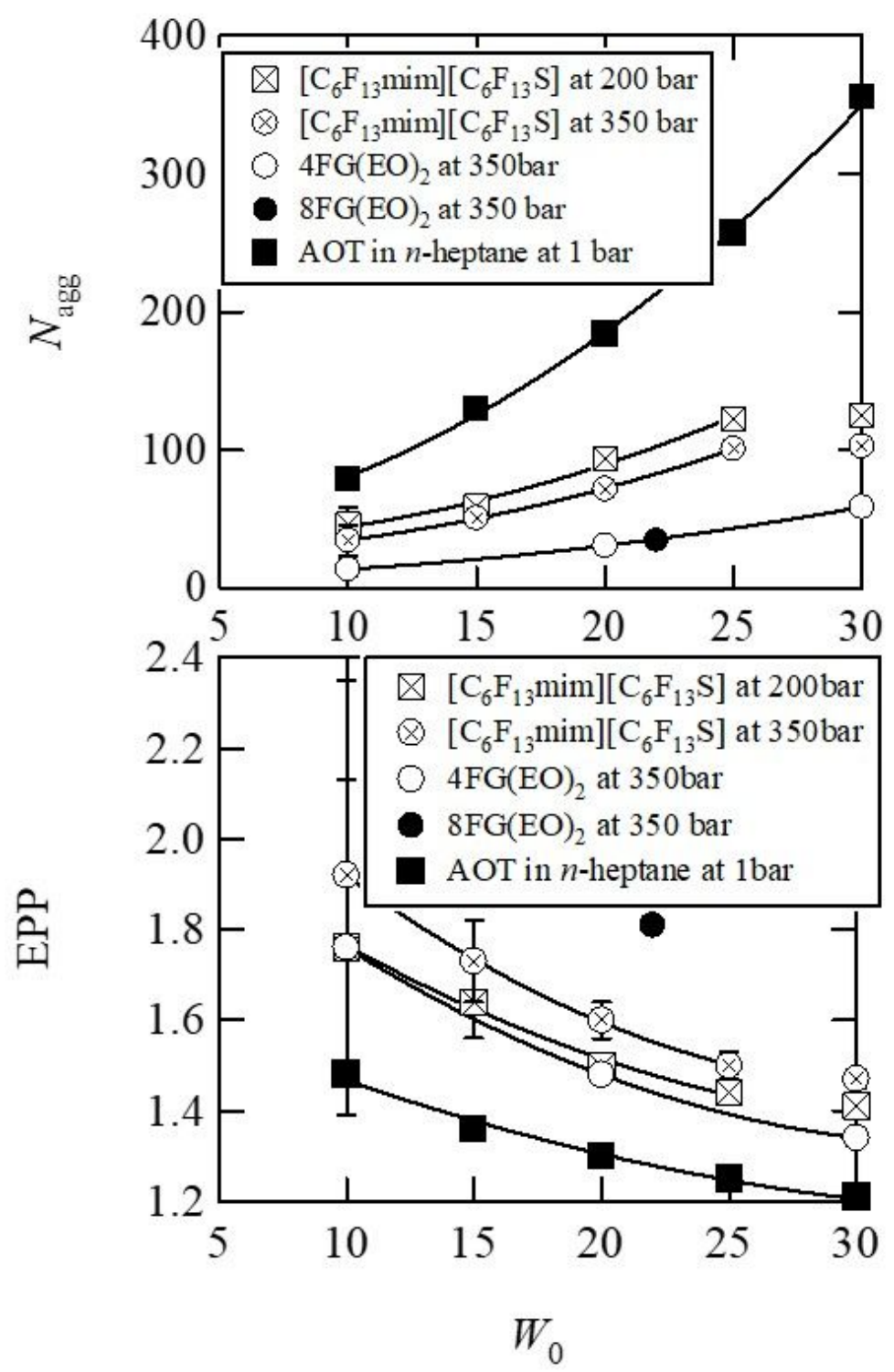

Figure 6. Changes in aggregation number $\left(N_{\text {agg }}\right)$ and effective packing parameter (EPP) of surfactants as a function of $W_{0}$. The data were for $\mathrm{D}_{2} \mathrm{O} / \mathrm{CO}_{2} \mu$ Es containing $16.7 \mathrm{mM}\left[\mathrm{C}_{6} \mathrm{~F}_{13} \mathrm{mim}\right]\left[\mathrm{C}_{6} \mathrm{~F}_{13} \mathrm{~S}\right]$ and $50 \mathrm{mM}$ double $\mathrm{FC}$-tail surfactants $\left(4 \mathrm{FG}(\mathrm{EO})_{2}\right.$ and $\left.8 \mathrm{FG}(\mathrm{EO})_{2}\right)$ at $45^{\circ} \mathrm{C}$ and $\mathrm{W} / n$-heptane $\mu$ Es containing $50 \mathrm{mM}$ AOT at $25^{\circ} \mathrm{C}$. 
As reported for other reverse micellar systems with $\mathrm{AOT}^{43}$ and the double FC-tail surfactants ${ }^{32}$, $N_{\text {agg }}$ and EPP for $\left[\mathrm{C}_{6} \mathrm{~F}_{13} \operatorname{mim}\right]\left[\mathrm{C}_{6} \mathrm{~F}_{13} \mathrm{~S}\right]$, respectively, increased and decreased with $W_{0}$, until the single phase $\mu$ Es became unstable and turbid phases appeared. This is consistent with an increase in aggregation number for both surfactant and water, as well as a change in surfactant molecular morphology from a reversed truncated cone to a cylindrical shape. These changes are linked to growth of reverse micelles and a decrease in negative curvature of the $\mathrm{W} / \mathrm{CO}_{2}$ interface with increasing water loading. As compared to the double FC-tail anionic $8 \mathrm{FG}(\mathrm{EO})_{2}$ and $4 \mathrm{FG}(\mathrm{EO})_{2}$ surfactants, the catanionic $\left[\mathrm{C}_{6} \mathrm{~F}_{13}\right.$ mim $]\left[\mathrm{C}_{6} \mathrm{~F}_{13} \mathrm{~S}\right]$

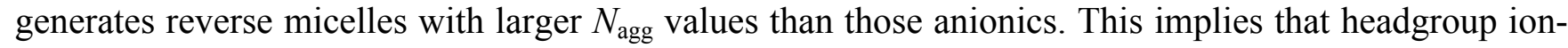
pairing promotes dense packing of $\left[\mathrm{C}_{6} \mathrm{~F}_{13} \mathrm{mim}\right]\left[\mathrm{C}_{6} \mathrm{~F}_{13} \mathrm{~S}\right]$ molecules to favor reverse micelles owing to reduced electrostatic repulsion between headgroups. On the other hand, lowering the pressure from 350 to 200 bar increased $N_{\text {agg }}$ and decreased EPP for $\left[\mathrm{C}_{6} \mathrm{~F}_{13} \mathrm{mim}\right]\left[\mathrm{C}_{6} \mathrm{~F}_{13} \mathrm{~S}\right]$, presumably due to a promotion of molecular aggregation owing to a reduction in $\mathrm{CO}_{2}$ solvation of the fluorinated tails at the lower $\mathrm{CO}_{2}$ density. Comparing the $A_{\mathrm{C} / \mathrm{W}}$ and $v_{\text {head }}$ values for $\left[\mathrm{C}_{6} \mathrm{~F}_{13} \mathrm{mim}\right]\left[\mathrm{C}_{6} \mathrm{~F}_{13} \mathrm{~S}\right]$ and the fluorinated double-tail $8 \mathrm{FG}(\mathrm{EO})_{2}$ and $4 \mathrm{FG}(\mathrm{EO})_{2}$, shows EPP was relatively close to that of $4 \mathrm{FG}(\mathrm{EO})_{2}$ but far from the value for 8FG(EO) $)_{2}$. Since these two surfactant classes have similar $A_{\mathrm{C} / \mathrm{W}}$ values, the difference in EPP between them is likely due to the fluorination level of the tails, namely longer FC-tails have the capacity to solvate more $\mathrm{CO}_{2}$ molecules, giving rise to greater effective tail volumes. As compared with AOT/W/n-heptane $\mu \mathrm{Es}{ }^{43}$, the $\mathrm{W} / \mathrm{CO}_{2} \mu \mathrm{Es}$ had smaller $N_{\text {agg }}$ and larger EPP values. This may be linked to differences in surfactant tail-solvent interactions, in other words, better solvation for the $\mathrm{FC}$-tails with $\mathrm{CO}_{2}$, as compared to for the AOT-tails with $n$-heptane.

This study demonstrated that the EPP of this catanionic surfactant, comparable to that of anionic double FC-tail surfactants, enables stabilization of $\mathrm{W} / \mathrm{CO}_{2}$ microemulsions with high $W_{0}$ values. This is very interesting as ionic headgroups themselves are known to be insoluble in supercritical $\mathrm{CO}_{2}$ and surfactants having ionic head groups usually require long and/or multiple $\mathrm{CO}_{2}$-philic tails to stabilize $\mathrm{W} / \mathrm{CO}_{2}$ microemulsions. However, it is now apparent that mixing single $\mathrm{CO}_{2}$-philic tail anions and cations, 
which are alone mostly insoluble and incompatible with $\mathrm{CO}_{2}$, is a useful approach to design $\mathrm{CO}_{2}$-philic surfactants. 


\section{Conclusions}

In order to meet requirements for potential use of $\mathrm{W} / \mathrm{CO}_{2} \mu \mathrm{Es}$ in industrial processes ${ }^{16-18}, \mathrm{~W} / \mathrm{CO}_{2}$ $\mu$ Es have been studied here, stabilized by ion-pairs of low F-content surfactant anions and cations, which themselves are individually insoluble and surface-inactive in $\mathrm{scCO}_{2}$. Because the ions are strongly associated, they cannot be easily dissociated under ambient conditions, as such, catanionic surfactants are not classified as normal ionic surfactants $25,44,45$.

This study was conceived to answer the question "why are ion-paired catanionic surfactants so effective at stabilizing high water content $\mathrm{W} / \mathrm{CO}_{2} \mu \mathrm{Es}$ "? The three new significant findings are:-

(1) The $\mathrm{W} / \mathrm{CO}_{2} \mu \mathrm{Es}$ with $\left[\mathrm{C}_{6} \mathrm{~F}_{13} \mathrm{mim}\right]\left[\mathrm{C}_{6} \mathrm{~F}_{13} \mathrm{~S}\right]$ solubilized an ionic dye which acts as a microenvironmental polarity probe, showing behavior similarity to other fluorinated anionic surfactants. ${ }^{9,12}$. On the other hand, the other catanionic surfactants with lower F-content did not solubilize the dye in $\mathrm{scCO}_{2}$, which is consistent with a lack of $\mathrm{W} / \mathrm{CO}_{2} \mu \mathrm{E}$ stabilization.

(2) Aggregation numbers of reverse micelles were about two times larger for $\left[\mathrm{C}_{6} \mathrm{~F}_{13}\right.$ mim $]\left[\mathrm{C}_{6} \mathrm{~F}_{13} \mathrm{~S}\right]$ compared with fluorinated double-tail anionic surfactants ${ }^{32}$ implying that electrostatic interactions between cationic and anionic headgroups promote close packing of surfactants to stabilize reverse micelles.

(3) Effective packing parameter (EPP) values of the catanionic surfactant in $\mathrm{W} / \mathrm{CO}_{2} \mu$ Es were relatively close to those found previously for the double perfluorooctyl-tail anionic surfactant $4 \mathrm{FG}(\mathrm{EO})_{2}{ }^{32}$. This indicates the electrostatic interactions resulted in a small interfacial areas and volumes for the catanionic headgroups, which is required for reversed curvature self-assembly, as found for the sulfonate headgroup of $4 \mathrm{FG}(\mathrm{EO})_{2}{ }^{32}$.

From these findings and previous studies ${ }^{25}$, the efficiency of $\left[\mathrm{C}_{6} \mathrm{~F}_{13} \mathrm{mim}\right]\left[\mathrm{C}_{6} \mathrm{~F}_{13} \mathrm{~S}\right]$ is likely related to EPP and HCB would be consistent with those of double FC-tail anionic surfactants ${ }^{32}$. Such a large EPP and a low HCB would be consistent with the small area and low ionicity of the catanionic headgroup, as compared to the related single-tail and single ionic headgroup anionic and cationic surfactants 
$\left(\mathrm{Na}\left[\mathrm{C}_{6} \mathrm{~F}_{13} \mathrm{~S}\right]\right.$ and $\left.\left[\mathrm{C}_{6} \mathrm{~F}_{13} \mathrm{mim}\right]\left[\mathrm{CH}_{3} \mathrm{SO}_{3}\right]\right)$. Hence, the concept of surfactant anion-cation pairing represents a new platform for developing $\mathrm{CO}_{2}$-philic surfactants and water-in- $\mathrm{CO}_{2}$ microemulsions for practical applications. This surfactant may be thought of as "the goose (cheap, simple-structure, and $\mathrm{CO}_{2}$-inactive surfactants) that lays the golden egg (super-efficient $\mathrm{CO}_{2}$-philic solubilizer)”. Using this platform but with highly-methylated alkyl tails, it should be possible to generate cheap and simple hydrocarbon surfactants as a super-efficient $\mathrm{CO}_{2}$-philic solubilizers, which is a long-cherished dream in supercritical $\mathrm{CO}_{2}$ science and technology. 


\section{ASSOCIATED CONTENT}

Supporting Information. Chemical structures of surfactants studied in earlier $\mathrm{W} / \mathrm{CO}_{2}$ microemulsion studies. Calculation of scattering length densities of reverse micelle shells $\left(\rho_{\text {shell }}\right)$, aqueous cores $\left(\rho_{\text {core }}\right)$, and $\mathrm{CO}_{2}\left(\rho_{\mathrm{CO} 2}\right)$ in the $\mathrm{D}_{2} \mathrm{O} / \mathrm{CO}_{2} \mu$ Es. Pressures at which clear single phases start to appear cloudy, $P_{\text {trans }}$ for $\left[\mathrm{C}_{6} \mathrm{~F}_{13} \mathrm{mim}\right]\left[\mathrm{C}_{6} \mathrm{~F}_{13} \mathrm{~S}\right] / \mathrm{W} / \mathrm{CO}_{2}$ mixtures. UV-vis absorption spectra for aqueous methyl orange (MO) solution $/ \mathrm{CO}_{2}$ mixtures with $16.7 \mathrm{mM}\left[\mathrm{C}_{5} \mathrm{~F}_{11} \mathrm{mim}\right]\left[\mathrm{C}_{5} \mathrm{~F}_{11} \mathrm{~S}\right]$ and $\left[\mathrm{C}_{6} \mathrm{~F}_{13} \mathrm{mim}\right]\left[\left(\mathrm{CF}_{3}\right)_{3} \mathrm{~S}\right]$. Change in absorbance of $\left[\mathrm{C}_{6} \mathrm{~F}_{13} \mathrm{mim}\right]\left[\mathrm{C}_{6} \mathrm{~F}_{13} \mathrm{~S}\right] / \mathrm{W} / \mathrm{CO}_{2} \mu$ Es with adding aqueous methyl orange (MO) solution. SANS profiles (Lin-Lin plots) for $16.7 \mathrm{mM}\left[\mathrm{C}_{6} \mathrm{~F}_{13} \mathrm{mim}\right]\left[\mathrm{C}_{6} \mathrm{~F}_{13} \mathrm{~S}\right] / \mathrm{D}_{2} \mathrm{O} / \mathrm{CO}_{2} \mu$ Es at various $W_{0}$ values and pressures. Estimation of $\mathrm{D}_{2} \mathrm{O}$ core radii in $16.7 \mathrm{mM}\left[\mathrm{C}_{6} \mathrm{~F}_{13} \mathrm{mim}\right]\left[\mathrm{C}_{6} \mathrm{~F}_{13} \mathrm{~S}\right] / \mathrm{D}_{2} \mathrm{O} / \mathrm{CO}_{2}$ reverse micelles by Guinier and Porod analyses of SANS data. Estimation of correlation length for $16.7 \mathrm{mM}$ $\left[\mathrm{C}_{6} \mathrm{~F}_{13} \mathrm{mim}\right]\left[\mathrm{C}_{6} \mathrm{~F}_{13} \mathrm{~S}\right] / \mathrm{D}_{2} \mathrm{O} / \mathrm{CO}_{2}$ microemulsions by Ornstein-Zernicke formalism. Prolate $\mathrm{D}_{2} \mathrm{O}$ core radius, aspect ratio, estimated specific viscosity for $16.7 \mathrm{mM}\left[\mathrm{C}_{6} \mathrm{~F}_{13} \mathrm{mim}\right]\left[\mathrm{C}_{6} \mathrm{~F}_{13} \mathrm{~S}\right] / \mathrm{D}_{2} \mathrm{O} / \mathrm{CO}_{2}$ microemulsions obtained by fitting theoretical curves of prolate ellipsoidal particle model to SANS data. Estimation of reverse micelle concentration, aggregation number, area per surfactant molecule, and effective packing parameter of the $\mathrm{D}_{2} \mathrm{O} / \mathrm{CO}_{2} \mu$ Es with $16.7 \mathrm{mM}\left[\mathrm{C}_{6} \mathrm{~F}_{13} \mathrm{mim}\right]\left[\mathrm{C}_{6} \mathrm{~F}_{13} \mathrm{~S}\right]$ at $45^{\circ} \mathrm{C}$ and 200 bar or 350 bar. This material is available free of charge via the Internet at "http://pubs.acs.org."

\section{AUTHOR INFORMATION}

Corresponding Author. *E-mail sagisaka@,hirosaki-u.ac.jp; FAX +81-172-39-3579 (M.S.)

Notes. The authors declare no competing financial interest.

\section{ACKNOWLEDGEMENT}

This project was supported by JSPS [KAKENHI, Grant-in-Aid for Scientific Research (B), No. 19H02504, Fostering Joint International Research (A), No. 15KK0221, Grant-in-Aid for Challenging Research (Exploratory), No.17K19002], and Leading Research Organizations (RCUK [through EPSRC EP/I018301/1], ANR [13-G8ME-0003]) under the G8 Research Councils Initiative for Multilateral 
Research Funding -G8-2012. We also acknowledge STFC for the allocation of beam time, travel, and consumables grants at ISIS. 


\section{References}

(1) Beckman, E. J. Supercritical and Near-Critical $\mathrm{CO}_{2}$ in Green Chemical Synthesis and Processing. $J$. Supercrit. Fluids 2004, 28, 121-191.

(2) Goetheer, E. L. V.; Vortaman, M. A. G.; Keurentjes, J. T. F. Opportunities for Process Intensification Using Reverse Micelles in Liquid and Supercritical Carbon Dioxide. Chem. Eng. Sci. 1999, 54, 15891596.

(3) Consani, K. A.; Smith, R. D. Observations on the Solubility of Surfactants and Related Molecules in Carbon Dioxide at $50{ }^{\circ} \mathrm{C}$. J. Supercrit. Fluids 1990, 3, 51-65.

(4) Ryoo, W.; Webber, S. E.; Johnston, K. P. Water-in-Carbon Dioxide Microemulsions with Methylated Branched Hydrocarbon Surfactants. Ind. Eng. Chem. Res., 2003, 42, 6348-6358.

(5) Lee, H.; Pack, J W.; Wang, W.; Thurecht, K. J.; Howdle, S. M. Synthesis and Phase Behavior of $\mathrm{CO}_{2^{-}}$ Soluble Hydrocarbon Copolymer: Poly(Vinyl Acetate-alt-Dibutyl Maleate). Macromolecules 2010, 43, 2276-2282.

(6) Shi, Q.; Jing, L.; Xiong, C.; Liu, C.; Qiao, W. Solubility of Nonionic Hydrocarbon Surfactants with Different Hydrophobic Tails in Supercritical $\mathrm{CO}_{2}$. J. Chem. Eng. Data 2015, 60, 2469-2476.

(7) Sagisaka, M.; Yoda, S.; Takebayashi, Y.; Otake, K.; Kitiyanan, B.; Kondo, Y.; Yoshino, N.; Takebayashi, K.; Sakai, H.; Abe, M. Preparation of a W/scCO 2 Microemulsion Using Fluorinated Surfactants. Langmuir 2003, 19, 220-225.

(8) Lee, C. T., Jr.; Psathas, P. A.; Johnston, K. P.; deGrazia, J.; Randolph, T. W. Water-in-Carbon Dioxide Emulsions: Formation and Stability. Langmuir 1999, 15, 6781-6791. 
(9) Johnston, K. P.; Harrison, K. L.; Klarke, M. J.; Howdle, S. M.; Heitz, M. P.; Bright, F. V.; Carlier, C.; Randolph, T. W. Water-in-Carbon Dioxide Microemulsions: A New Environment for Hydrophiles Including Proteins. Science 1996, 271, 624-626.

(10) Zielinski, R. G.; Kline, S. R.; Kaler, E. W.; Rosov, N. A Small-Angle Neutron Scattering Study of Water in Carbon Dioxide Microemulsions. Langmuir 1997, 13, 3934-3937.

(11) Niemeyer, E. D.; Bright, F. V. The pH within PFPE Reverse Micelles Formed in Supercritical $\mathrm{CO}_{2}$. J. Phys. Chem. B 1998, 102, 1474-1478.

(12) Sagisaka, M.; Iwama, S.; Yoshizawa, A.; Mohamed, A.; Cummings S.; Eastoe, J. An Effective and Efficient Surfactant for $\mathrm{CO}_{2}$ Having Only Short Fluorocarbon Chains. Langmuir 2012, 28, 10988-10996.

(13) Sagisaka, M.; Ono, S.; James, C.; Yoshizawa, A.; Mohamed, A.; Guittard, F.; Enick, R. M.; Rogers, S. E.; Czajka, A.; Hill, C.; Eastoe, J. Anisotropic Reversed Micelles with Fluorocarbon-Hydrocarbon Hybrid Surfactants in Supercritical $\mathrm{CO}_{2}$, Colloids Surf. B 2018, 168, 201-210.

(14) Li, Q.; Li, T.; Wu, J. Water Solubilization Capacity and Conductance Behaviors of AOT and NaDEHP Systems in the Presence of Additives. Colloids Surf. A 2002, 197, 101-109.

(15) Sagisaka, M.; Hino, M.; Sakai, H.; Abe, M.; Yoshizawa, A. Water/Supercritical $\mathrm{CO}_{2} \mathrm{Microemulsions}$ with a Fluorinated Double-tail Surfactant for Syntheses of Semiconductor Ultrafine Particles. J. Jpn. Colour Soc. Mater. 2008, 81, 331-340.

(16) Holmes, J. D.; Steytler, D. C.; Rees, G. D.; Robinson B. H. Bioconversions in a Water-in-CO Microemulsion. Langmuir 1998, 14, 6371-6376.

(17) Van Roosmalen, M. J. E.; Woerlee, G. F.; Witkamp, G. J.; Surfactants for Particulate Soil Removal in Dry-cleaning with High-pressure Carbon Dioxide. J. Supercrit. Fluids 2004, 30, 97-109. 
(18) Luo, D.; Qiu, T.; Lu, Q. Ultrasound-assisted Extraction of Ginsenosides in Supercritical $\mathrm{CO}_{2}$ Reverse Microemulsions. J. Sci. Food Agric. 2007, 87, 431-436.

(19) Kravetz, L.; Guin, K. F. Effects of Surfactant Structure on Stability of Enzymes Formulated into Laundry Liquids. J. Am. Oil Chem. Soc. 1985, 62, 943-949.

(20) Sagisaka, M.; Fujii, T.; Koike, D.; Yoda, S.; Takebayashi, Y.; Furuya, T.; Yoshizawa, A.; Sakai, H.; Abe, M.; Otake, K. Surfactant-Mixing Effects on the Interfacial Tension and the Microemulsion Formation in Water/Supercritical $\mathrm{CO}_{2}$ System. Langmuir 2007, 23, 2369-2375.

(21) Sagisaka, M.; Koike, D.; Mashimo, Y.; Yoda, S.; Takebayashi, Y.; Furuya, T.; Yoshizawa, A.; Sakai, H.; Abe, M.; Otake, K. Water/supercritical $\mathrm{CO}_{2}$ Microemulsions with Mixed Surfactant Systems. Langmuir 2008, 24, 10116-10122.

(22) Huang, J.-B.; Zhao, G. -X. Formation and Coexistence of the Micelles and Vesicles in Mixed Solution of Cationic and Anionic Surfactant. Colloid Polym. Sci. 1995, 273, 156-164.

(23) Upadhyaya, A.; Acosta, E. J.; Scamehorn, J. F.; Sabatini, D. A. Microemulsion Phase Behavior of Anionic-Cationic Surfactant Mixtures: Effect of Tail Branching. J. Surfactants Deterg. 2006, 9, 169-179.

(24) Eastoe, J.; Dalton, J.; Rogueda, P.; Sharpe, D.; Dong, J.; Webster, J. R. P. Interfacial Properties of a Catanionic Surfactant. Langmuir 1996, 12, 2706-2711.

(25) Sagisaka, M.; Saito, T.; Yoshizawa, A.; Rogers, S. E.; Guittard, F.; Hill, C.; Eastoe, J.; Blesic, M. Water-in- $\mathrm{CO}_{2}$ Microemulsions Stabilized by Fluorinated Cation-Anion Surfactant Pairs. Langmuir 2019, $35,3445-3454$.

(26) Pleines, M.; Kunz, W.; Zemb, T. Understanding and Prediction of the Clouding Phenomenon by Spontaneous and Effective Packing Concepts. J. Surfact. Deterg. 2019, 22, 1011-1021. 
(27) Ontiveros, J. F.; Pierlot, C.; Catté, M.; Molinier, V.; Pizzino, A.; Salager, J.-L.; Aubry, J.-M. Classification of ester oils according to their Equivalent Alkane Carbon Number (EACN) and asymmetry of fish diagrams of $\mathrm{C}_{10} \mathrm{E}_{4} /$ ester oil/water systems. J. Colloid Interf. Sci. 2013, 403, 67-76.

(28) Israelachvili, J. N. Measurements of Hydration Forces Between Macroscopic Surfaces. Chem. Scr. $1985,25,7-14$

(29) Nagarajan, R. Molecular Packing Parameter and Surfactant Self-Assembly: The Neglected Role of the Surfactant Tail. Langmuir 2002, 18, 31-38.

(30) Span, R.; Wagner, W. A New Equation of State for Carbon Dioxide Covering the Fluid Region from the Triple-Point Temperature to $1100 \mathrm{~K}$ at Pressures up to $800 \mathrm{MPa}$. J. Phys. Chem. Ref. Data 1996, 25, $1509-1596$.

(31) Kotlarchyk, M.; Chen, S.-H.; Huang, J. S.; Kim, M. W. Structure of Three-Component. Microemulsions in the Critical Region Determined by Small Angle Neutron Scattering Data. Phys. Rev. A 1984, 29, 2054-2069.

(32) Sagisaka, M.; Iwama, S.; Ono, S.; Yoshizawa, A.; Mohamed, A.; Cummings, S.; Yan, C.; James, C.; Rogers, S. E.; Heenan, R. K.; Eastoe, J. Nanostructures in Water-in- $\mathrm{CO}_{2}$ Microemulsions Stabilized by Double-chain Fluorocarbon Solubilizers. Langmuir 2013, 29, 7618-7628.

(33) Guinuier, A.; Fournet, G. Small-Angle Scattering of X-Rays, Wiley, New York, 1956.

(34) Karukstis, K. K.; Savin, D. A.; Loftus, C.T.; D’Angelo, N. D. Spectroscopic Studies of the Interaction of Methyl Orange with Cationic Alkyltrimethylammonium Bromide Surfactants. J. Colloid Interf. Sci. 1998, 203, 157-163.

(35) Kline, S. R. Reduction and Analysis of SANS and USANS Data Using IGOR Pro. J. Appl. Cryst. 2006, 39, 895-900. 
(36) Almásy, L.; Turmine, M.; Perera, A. Structure of Aqueous Solutions of Ionic Liquid 1-Butyl-3methylimidazolium Tetrafluoroborate by Small-Angle Neutron Scattering. J. Phys. Chem. B 2008, 112, 2382- 2387.

(37) Zemb, T. N.; Klossek, M.; Lopian, T.; Marcus, J.; Schöettl, S.; Horinek, D.; Prevost, S. F.; Touraud, D.; Diat, O.; Marčelja, S.; Kunz, W. How to Explain Microemulsions Formed by Solvent Mixtures without Conventional Surfactants. Proc. Natl. Acad. Sci. 2016, 113, 4260-4265.

(38) Grimaldi, N.; Rojas, P. E.; Stehle, S.; Cordoba, A.; Schweins, R.; Sala, S.; Luelsdorf, S.; Piña, D.; Veciana, J.; Faraudo, J.; Triolo, A.; Braeuer, A. S.; Ventosa, N. Pressure-Responsive, Surfactant-Free $\mathrm{CO}_{2}$-Based Nanostructured Fluids. ACS Nano 2017, 11, 10774-10784.

(39) Weber, A.; Stühn, B. Structure and Phase Behavior of Polymer Loaded Non-ionic and Anionic Microemulsions. J. Chem. Phys. 2016, 144, 144903.

(40) Williams, D. F. Extraction with Supercritical Gases. Chem. Eng. Sci. 1981, 36, 1769-1788.

(41) Orr, F. M.; Taber, J. J. Use of Carbon Dioxide in Enhanced Oil Recovery. Science 1984, 224, 563569.

(42) Sagisaka, M.; Fujii, T.; Ozaki, Y.; Yoda, S.; Takebayashi, Y.; Kondo, Y.; Yoshino, N.; Sakai, H.; Abe, M.; Otake, K. Interfacial Properties of Branch-Tailed Fluorinated Surfactants Yielding a Water/Supercritical $\mathrm{CO}_{2}$ Microemulsion. Langmuir 2004, 20, 2560-2566.

(43) Nave, S.; Eastoe, J.; Heenan, R.K.; Steytler, D.; Grillo, I. What is so Special about Aerosol-OT? 2. Microemulsion Systems. Langmuir 2000, 16, 8741-8748.

(44) Yin, H.; Lin, Y.; Huang, J.; Ye, J. Temperature-Induced Vesicle Aggregation in Catanionic Surfactant Systems: The Effects of the Headgroup and Counterion. Langmuir 2007, 23, 4225-4230. 
(45) Nakama, Y.; Harusawa, F.; Murotani, I. Cloud Point Phenomena in Mixtures of Anionic and Cationic Surfactants in Aqueous Solution. J. Surfactants Deterg. 1990, 67, 717-721. 


\section{TOC (Revised)}

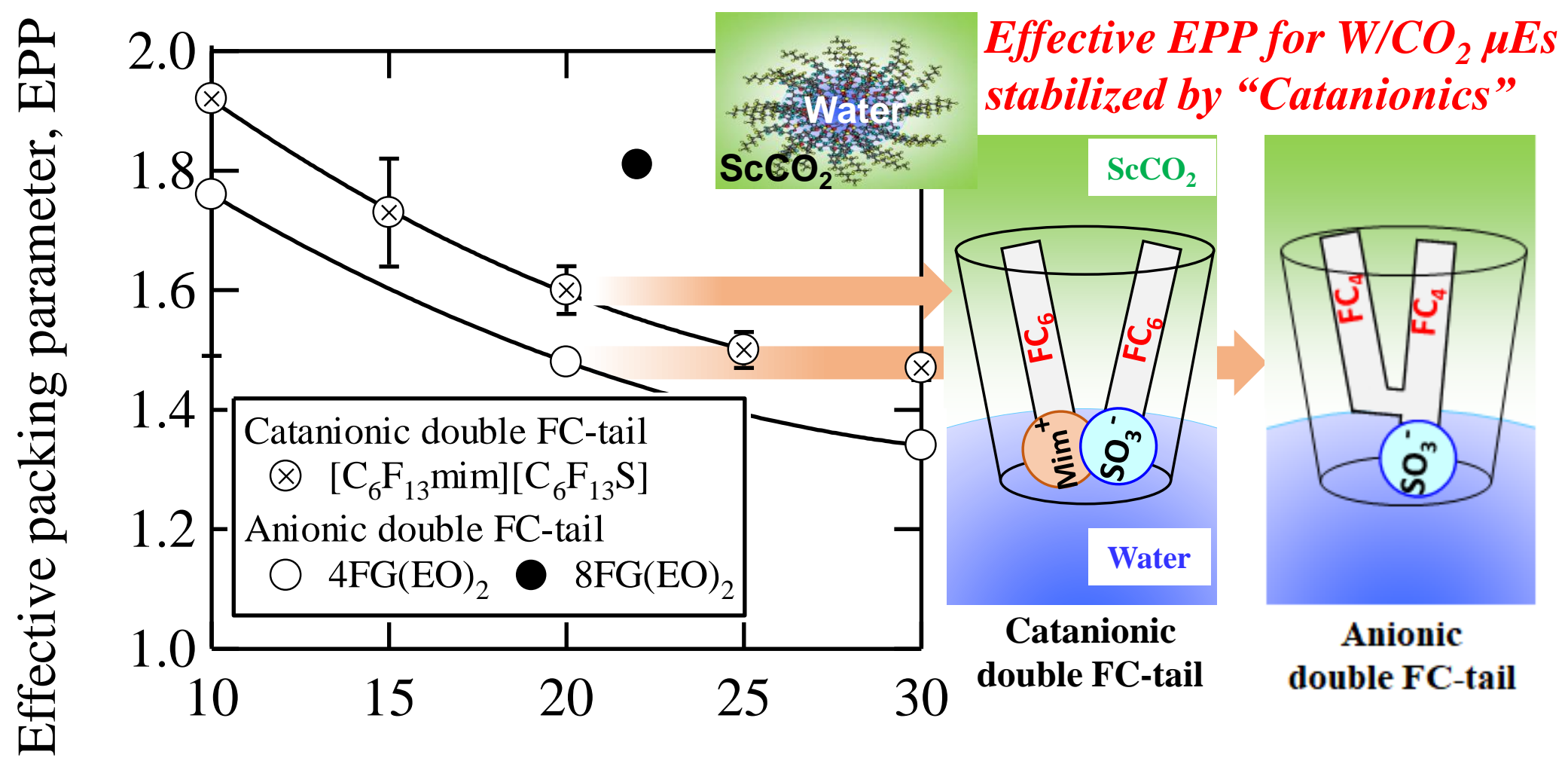

Water-to-surfactant molar ratio, $W_{0}$ 